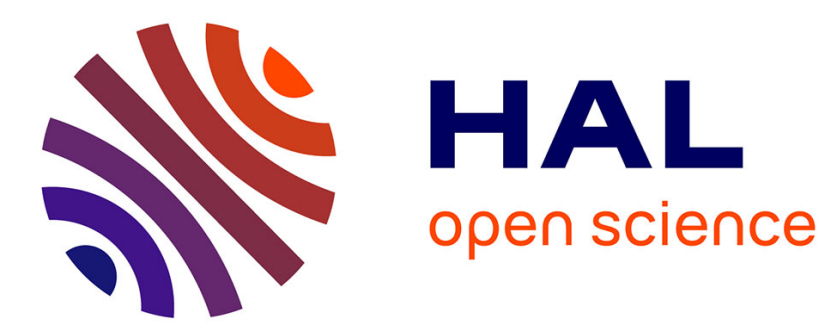

\title{
Beyond the hype surrounding biofuel cells: What's the future of enzymatic fuel cells?
}

\author{
Serge Cosnier, Andrew Gross, Fabien Giroud, Michael Holzinger
}

\section{To cite this version:}

Serge Cosnier, Andrew Gross, Fabien Giroud, Michael Holzinger. Beyond the hype surrounding biofuel cells: What's the future of enzymatic fuel cells?. Current Opinion in Electrochemistry, 2018, 12, pp.148-155. 10.1016/j.coelec.2018.06.006 . hal-02007139

\section{HAL Id: hal-02007139 \\ https://hal.science/hal-02007139}

Submitted on 19 Nov 2020

HAL is a multi-disciplinary open access archive for the deposit and dissemination of scientific research documents, whether they are published or not. The documents may come from teaching and research institutions in France or abroad, or from public or private research centers.
L'archive ouverte pluridisciplinaire HAL, est destinée au dépôt et à la diffusion de documents scientifiques de niveau recherche, publiés ou non, émanant des établissements d'enseignement et de recherche français ou étrangers, des laboratoires publics ou privés. 


\title{
Review Article \\ Beyond the hype surrounding biofuel cells: What's the future of enzymatic fuel cells?
}

\author{
Serge Cosnier*, Andrew J. Gross, Fabien Giroud and \\ Michael Holzinger
}

\section{After a short comparison of biofuel cells based on enzymes and microorganisms, several important developments and applications of enzymatic fuel cells (EFCs) are discussed. This discussion emphasizes how to evaluate the performance of EFCs, and highlights the influence of temperature and how it must be carefully considered for practical use of EFCs as power sources. Some of the latest and most important innovations in EFC design using buckypapers and redox nanoparticles are briefly reviewed.}

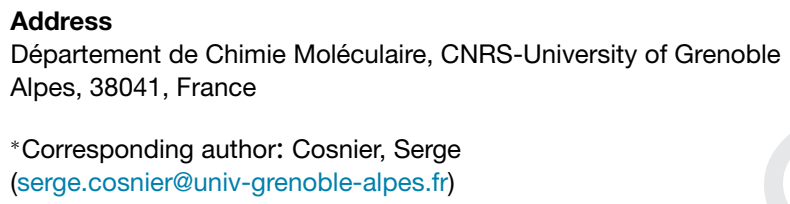

\section{Introduction}

The development of sustainable and renewable energy sources with greater respect for the environment is a crucial challenge for the 21st century. Among various alternative energy sources, fuel cells have generated great interest for the production of clean electrical energy. Fuel cells generate power through electrochemical reactions via the oxidation of fuels such as hydrogen and alcohols at the anode, and the reduction of oxidants, typically oxygen, at the cathode. Fuel cells will produce electricity with heat and water as by-products providing that fuel and oxidant are available. Enzymatic fuel cells (EFCs) and microbial fuel cells (MFCs) are sub-categories of fuel cells that share similar operational principles for energy production [1,2]. However, biological fuel cells are not intended to over- come the depletion of fossil fuels and enter the category of renewable energy resources such as hydroelectric, solar, and wind energy. The scope of applications for EFCs and MFCs is restricted, at least for now, to electricity generation for powering microelectronic systems such as actuators and sensors $\left[3,4,5^{\bullet \bullet}, 6^{\bullet}\right]$ and for use in environmental remediation and sanitation systems $\left[7^{\circ}, 8\right]$.

Enzymatic and microbial biofuel cells differ vastly in terms of their volumetric size $\left(\mathrm{cm}^{3}\right.$ to $\left.\mathrm{m}^{3}\right)$, power density output ( $\mu \mathrm{W}$ to $\mathrm{mW}$ ) and their targeted applications (smallto large-scale). Another important consideration lies in the cost of the biocatalyst, which ranges from low-cost bacteria or yeast cells, for MFCs, to the higher cost of purified wild-type and engineered enzymes for EFCs. MFCs have been successfully employed as long-term powergenerating systems, for example, for self-powered sensors placed in "hostile" environments or remote locations [9]. Although MFCs have successfully powered different generations of robots, this approach remains at the academic level because of limitations such as the large volume of MFCs required and their long amortization cost [8]. Nevertheless, MFCs constitute an original and ecofriendly system for producing electrical energy, e.g. from waste, and have become an attractive bioreactor concept for purification of wastewaters. EFCs on the other hand, because of their superior power density and compactness, are better suited to miniaturization and use as portable power sources for wearable and implantable electronics devices. EFCs appear to carry greater promise as batteryfree power solutions, but it is necessary to define if this is a simple scientific curiosity or if their potentialities really do have conceivable real-world applications. This opinion article attempts to shed light on some hitherto neglected facets of EFCs, to briefly revisit their possible applications, and to reveal new insights concerning future directions. It is emphasized that this review does not cover all of the exciting facets and developments in EFG research. Recent reviews are available for further information on important topics such as the evolution of bioinspired strategies for the electrical wiring of enzymes and the development of high surface area bioelectrodes $[10,11]$. Notable innovations on high surface area electrodes include the hierarchically porous $\mathrm{MgO}$-templated carbon and carbon nanotube (CNT) yarn textile electrodes $\left[12^{\circ}, 13\right]$. 
At the very beginning, EFCs were developed to generate electrical energy mainly through the oxidation of saccharides at the anode coupled with the red]uction of oxygen at the cathode $[4,14]$. In addition to glucose, which is by far the most exploited fuel at the anode, other fuels that have been explored include fructose, pyruvate, hydrogen, lactate, methanol and ethanol $[3,4,6]$. Since glucose is an essential and relatively abundant source of energy in living organisms, special attention has been given to the development of implantable EFCs for powering implanted medical devices from physiological fluids [15]. In parallel, EFCs are considered for powering portable electronic devices such as mobile phones, sensors, digital music players, laptops, and GPS systems. A fascinating flagship application, proposed by many authors for more than a decade, is the use of EFCs as a lifetime power supply for cardiac pacemakers. However, despite all of the promises, there are many hurdles and roadblocks to overcome. It is now time to recognize that the pacemaker application is unrealistic. Besides sterilization and biocompatibility problems, the major issue with implanted EFCs is their operational stability that ranges from a few hours to one year compared to $5-8$ years for sealed batteries [16].

A recent and promising generation of biofuel cells concerns $\mathrm{H}_{2} / \mathrm{O}_{2}$ EFCs $\left[17^{\bullet}, 18^{\bullet \bullet}\right]$. The adsorption, entrapment and chemical immobilization of NiFe and FeFe hydrogenases, and their "electrical wiring", is at the origin of bioanodes for electrocatalytic interconversion of protons and hydrogen [19-23]. Hydrogenases entrapped in redox polymers are particularly active for bioelectrocatalytic hydrogen oxidation $\left[24^{\circ}, 25,26\right]$. Recent hydrogenase electrodes exhibit characteristics that are competitive to those of Pt-based electrodes such as long-term stability, $\mathrm{mW}$ power densities, insensitivity to fuel impurities such as $\mathrm{CO}$ and sulfides, and tolerance to $\mathrm{O}_{2}$. EFCs with hydrogenase bioanodes thus show great promise as noble metal-free hydrogen fuel cells [27-31]. Compared with glucose EFCs, a major advantage of hydrogen EFCs lies in the size of the fuel. Hydrogen is markedly smaller than glucose or various redox mediators used for electrical enzyme wiring. The small size can thus be exploited, via careful electrode design with permselective membranes, to prevent the leakage of redox mediators whilst allowing $\mathrm{H}_{2}$ to efficiently diffuse into the cell. Hydrogen EFCs have been successfully developed with gas-diffusion electrodes, like air-breathing cathodes or $\mathrm{H}_{2}$-breathing anodes, which make it possible to increase the availability of dissolved $\mathrm{O}_{2}$ and $\mathrm{H}_{2}$ in quiescent solutions. This is an essential development for portable EFCs used outside of the body. Owing to electrode nanostructuration, and improvements in enzyme orientation and electrical wiring, great improvements in power densities have been achieved, which can match, or even surpass, the performance of glucose EFCs. However, the use of hydrogen for EFCs confronts us with problems of $\mathrm{H}_{2}$ storage and transport. This is in contrast to the use of glucose, which is a safe, abundant and easy-to-handle energy compound. Hydrogen can be physically stored as either a gas or a liquid but generally requires high pressure and large volume tanks. Practical high density hydrogen storage remains a major challenge for EFCs dedicated to portable applications.

\section{How to define EFC power?}

One of the problematic points for the comparison and continuous optimization of EFC performance concerns their power output and how it is defined. As already pointed out by Katz and coworkers, the power density of an $\mathrm{EFC}$ is an important parameter that must be associated with the real power generated by the EFC in order to determine which applications can actually be considered [32]. There are a multitude of electronic and wireless electrical products that consume microwatt to milliwatt powers during operation. Many electronic devices have multiple power modes such as a "standby" mode, where low power is consumed, and "active modes", for example, for data transmission. High milliwatt powers, for example, may therefore only be required for very short periods of peak activity. Future advances in ultra-low power and low voltage electronics in the next decade are expected which will further valorise energy-harvesting devices with $\mu \mathrm{W}$ to $\mathrm{mW}$ outputs. For instance, an ultra-low power $3.5 \mu \mathrm{W}$ consuming cell phone without a battery is under development [33].

In the research field of biological fuel cells, power densities can be misleading. For example, microwatt power densities obtained using microelectrodes seem extremely attractive, but in reality, are almost useless when the actual power output is on the order of nanowatts. Another issue for bioelectrodes is that the power does not evolve proportionally to the surface area owing to the electrode morphology that plays, for example, on the continuous supply and removal of reactants and products. The power is highly dependent on electrode morphology, including the structure and thickness of the adsorbed enzymes, and the crucial mass transport and charge propagation processes that occur inside and outside of the biocatalyst layer(s) [34].

Regarding the electrode architecture, which ranges from simple planar electrodes with monolayers of enzymes to 3D-structured mesoporous carbon, CNT pellets, and GNT yarns with embedded enzymes, the electroactive surfaces and enzyme loadings can be vastly different $\left[12^{\circ}, 13\right]$. Despite this, the power densities of biofuel cells are conventionally calculated only with respect to the geometric surface of the electrodes. So what about the fact that most bioelectrodes are now based on 3D architectures with huge differences in electrode thickness and surface area? Another difficulty in defining power also lies sometimes in the design of EFCs that exploit anodes and cathodes with different sizes. For example, a $\mathrm{H}_{2} / \mathrm{O}_{2}$
131 
EFC combines a $6 \mathrm{~cm}^{2}$ bilirubin oxidase-modified cathode with a $1.2 \mathrm{~cm}^{2}$ hydrogenase-modified anode to balance the catalytic performance as a function of the $\mathrm{H}_{2}$-air mixture used $\left[18^{\circ}\right]$. The raw power output must surely now be reported in all cases? It now seems valuable to define the volumetric power of bioelectrodes in $\mathrm{mW} \mathrm{cm} \mathrm{cm}^{-3}$, especially if $3 \mathrm{D}$ electrodes with thicknesses ranging from micrometres and centimetres are being used. Indeed, we have recently reported the raw power together with the current density of an EFG in both $\mathrm{cm}^{2}$ and $\mathrm{cm}^{3}\left[35^{\circ}\right]$. A crucial power definition for the future, which will become more relevant as EFCs emerge for practical device powering, is the volumetric power density of the single or stacked EFG in $\mathrm{cm}^{3}$, taking into account the space between the anode(s) and the cathode(s) and the entire cell. For a single EFC, the optimisation of distance between the bioelectrodes, which also plays on the resistance, substrate supply, and by-product formation, will become a key consideration for the power/size ratio.

\section{Influence of temperature on the operation of EFCs}

Besides the difficulty of designing EFCs whose enzymatic reactions at the anode and the cathode must operate at the same $\mathrm{pH}$, another major problem for EFCs concerns the influence of temperature on the rate and stability of enzyme-catalyzed reactions, and hence on EFC performance. This key parameter has often been underestimated or neglected, yet can drastically change the perspectives of EFCs for different applications. Depending on the origin of the enzyme, the temperature/activity profile may show optima ranging from low temperatures $\left(3-5^{\circ} \mathrm{C}\right)$ to high temperatures $\left(50-80^{\circ} \mathrm{C}\right)$. Regarding the more common glucose $/ \mathrm{O}_{2} \mathrm{EFCs}$, cathodes are usually based on immobilized bilirubin oxidase or laccase for the reduction of oxygen. Laccase from Trametes versicolor exhibits its greatest stability at $30^{\circ} \mathrm{C}$ and undergoes a thermal deactivation above $50^{\circ} \mathrm{C}$, which for example, leads to a loss in activity of 53\% and 90\% after 6 and $48 \mathrm{hrs}$, respectively [36]. In contrast, bilirubin oxidase from Myrothecium verrucaria is considered relatively stable in the range of $40-60{ }^{\circ} \mathrm{C}$ but loses $40 \%$ of its activity when the temperature decreases from 40 to $25^{\circ} \mathrm{C}$ [37]. At the anode, the oxidation of glucose is mainly catalyzed by glucose oxidase. The latter has a maximum activity at $20-35^{\circ} \mathrm{C}$ but retains only $65 \%$ of its activity at $45^{\circ} \mathrm{C}$, and exhibits total thermal inactivation at $60^{\circ} \mathrm{C}$ [38-40].

The different thermal behavior of oxidoreductase enzymes is a real problem for the performance and stability of EFCs, especially considering that an EFC must employ two very different enzymes at the anode and cathode. The influence of temperature may call into question the use of EFCs for powering portable electronics exposed to certain environmental conditions with wide variations in temperature. This problem actually becomes an attractive point for implanted biofuel cells, of which one of the main features is their exposure, by definition, to a con- stant physiological temperature of $37^{\circ} \mathrm{C}$. Nevertheless, this does not mean that relevant enzymes are unsuitable for operation at elevated temperatures. In fact, it appears that the power of EFCs can be increased by increasing the temperature, as demonstrated by Lojou and coworkers for $\mathrm{H}_{2} / \mathrm{O}_{2}$ EFCs using thermostable enzymes such as hydrogenase from Aquifex aeolicus and bilirubin oxidase from Bacillus pumilus $\left[17^{\bullet}, 41\right]$. High power densities have been obtained under these (relatively) mild conditions, making it possible to power a wireless transmission system [42] as illustrated in Figure 1. However, to accurately evaluate the performance and practicality of such hydrogen EFCs, it is necessary to also consider the power required to maintain the EFC at $60^{\circ} \mathrm{C}$. Rather than the possibility for improved EFC power output, the main advantage of this approach lies in the use of thermostable enzymes thatallow the EFC to withstand significant temperature variations (e.g. from $30-80^{\circ} \mathrm{C}$ ) without denaturation.

As well as temperature considerations, the type of solution used in the biofuel cell is another critical but often overlooked factor in EFC research. Until now, relatively few studies have investigated EFC performance in matrices for practical applications such as biological fluids, environmental waters or wastewater. The vast majority of experiments have simply been performed in aqueous buffer solutions. Towards human body-integrated applications, recent studies have started to address bioelectrode and EFC performance directly in human serum, urine, saliva and blood [43-47]. These works have highlighted complications that reduce EFC power output and stability due to low substrate concentrations and interferences from ascorbic acid, chloride, uric acid and biophysical matter. Reported strategies to address interferences include the use of a dialysis bag as a protective membrane, a strategy first reported by our group in 2010 for an EFC implanted in a rat [48].

\section{Buckypaper-based EFCs for wearables and implantables devices}

Carbon nanotubes are a widely used material in bioelectrode design $\left[6^{\circ}\right]$. In the last 5-7 years, free-standing thin films of CNTs, called buckypapers, have emerged for use in biofuel cells $\left[49^{\circ}\right]$. Buckypapers are in fact at the origin of remarkable advances in the field of EFCs [50-53], particularly concerning implanted biofuel cells $\left[51^{\bullet \bullet}, 54^{\circ \bullet}\right]$. Buckypaper films are self-supporting macroscopic sheets of entangled CNTs held together by $\pi-\pi$ stacking interactions with an average thickness of $5-200 \mu \mathrm{m}$. Buckypapers are typically obtained either from a commercial source (e.g. NanoTechLabs Inc.) via roll-to-roll processing, or via conventional vacuum filtration of a dispersion of CNTs in organic or aqueous solution. Compared with classical electrodes based on glassy carbon, buckypapers constitute a break of concept since they are the electrode itself. Furthermore, these electrodes are lighter, more compact and flexible, and more easily processed into 


\section{Bioelectrochem}

Figure 1

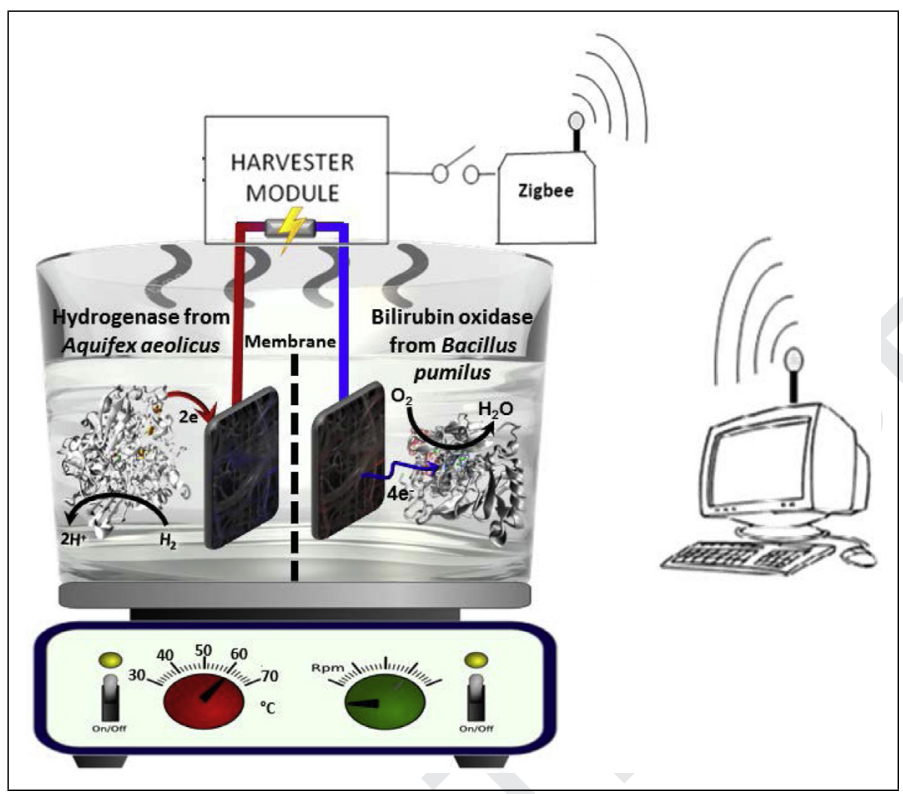

Schematic presentation of a $\mathrm{H}_{2} / \mathrm{O}_{2}$ biofuel cell setup with thermophilic biocatalysts producing sufficient power at elevated temperature for supplying a wireless transmission system.

different shapes and sizes compared to electrodes based on glassy carbon. Until now, buckypapers have mainly been modified via $\pi$-stacking interactions with pyrene derivatives, which are used for covalent or non-covalent binding of enzymes and/or mediators, and have led to high performance bioelectrodes for in-vivo biofuel cells. In particular, Katz and coworkers have highlighted the practical advantages of buckypaper for implantation compared to traditional bulk electrodes (e.g. glassy carbon), such as their ideal microscale thickness and tunable dimensions $\left[54^{\bullet \bullet}, 55\right]$. Owing to attractive properties such as their flexibility, Minteer and coworkers developed a miniaturized buckypaper-based lactate $/ \mathrm{O}_{2}$ EFC embedded in a contact lens for operation in human tears [56]. Besides increasing the length and alignment of CNTs, another possibility to improve the strength and flexibility of buckypapers lies with the incorporation of an organic crosslinker. An elegant approach is to "molecularly" cross-link the CNTs of buckypaper with bis-pyrene-2,2' azino-bis(3-ethylbenzothiazoline-6-sulphonic acid) (bispyrene-ABTS), which enhances the mechanical stability of the buckypaper and gives it redox properties for wiring multicopper enzymes [57,58]. Furthermore, Cosnier and coworkers reported a new approach for fabricating robust and flexible buckypaper bioelectrodes based on the intimate association of CNTs and linear polynorbornene polymers $[59,60]$. These polymers were functionalized with pyrene groups, for cross-linking, and activated esters, for covalent attachment of enzymes and/or molecules for electrical enzyme wiring. Besides improved flexibility and handleability, enzyme-modified buckypapers are proving to be effective bioelectrodes for EFCs and will certainly 326 have an important role to play in future implantable or 327 wearable EFCs. To improve the limited performance of biocathodes, which commonly suffer from oxygen limitations, we note the cathode design from Atanassov and his colleagues that combined a gas-diffusion layer with a catalytic buckypaper such that the individual benefits of both materials could be exploited [61]. Some examples of buckypaper interfaces and their applications are sketched in Figure 2.

Perspectives on nanoparticle-based rechargeable EFCs EFCs are faced with two major technological bottlenecks that currently block their development, namely their short lifetime, and to a lesser degree, their weak power output. The low stability of EFCs is largely related to the deactivation of immobilized enzymes, the intrinsic catalytic component, and this seems somewhat ineluctable. In particular, enzymes have a limited stability that depends on the environment in which they are used (temperature, $\mathrm{pH}$, inhibitors...). Weak power output is related to factors including the sub-optimal fixation of enzymes and redox mediators to electrodes, which reduces markedly their mobility and flexibility, and in some cases, fixes enzymes in poor orientations for electron transfer. An attractive solution lies in the development of bioelectrodes based on confined solutions of enzymes and supramolecular assemblies of redox mediators or electron transfer-promoting molecules. The electrical wiring of enzymes in solution with electrodes forming a conductive chamber only permeable to the enzyme 


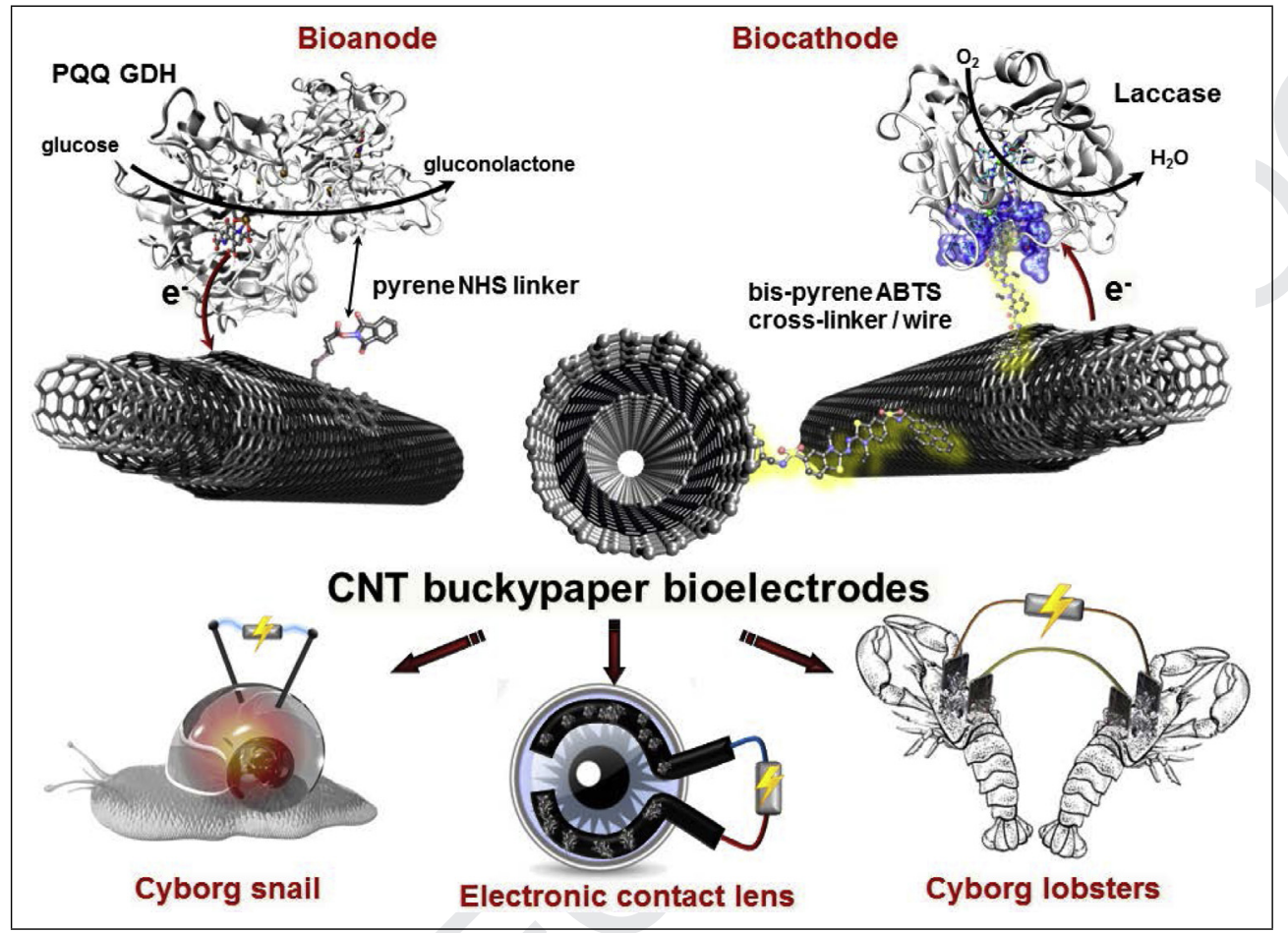

Illustration of buckypaper-based bioelectrodes with various immobilization and enzyme wiring functions (pyrroloquinoline quinone glucose dehydrogenase (PQQ GDH) and laccase) for efficient energy harvesting wearable and implantable biofuel cells.

Figure 3

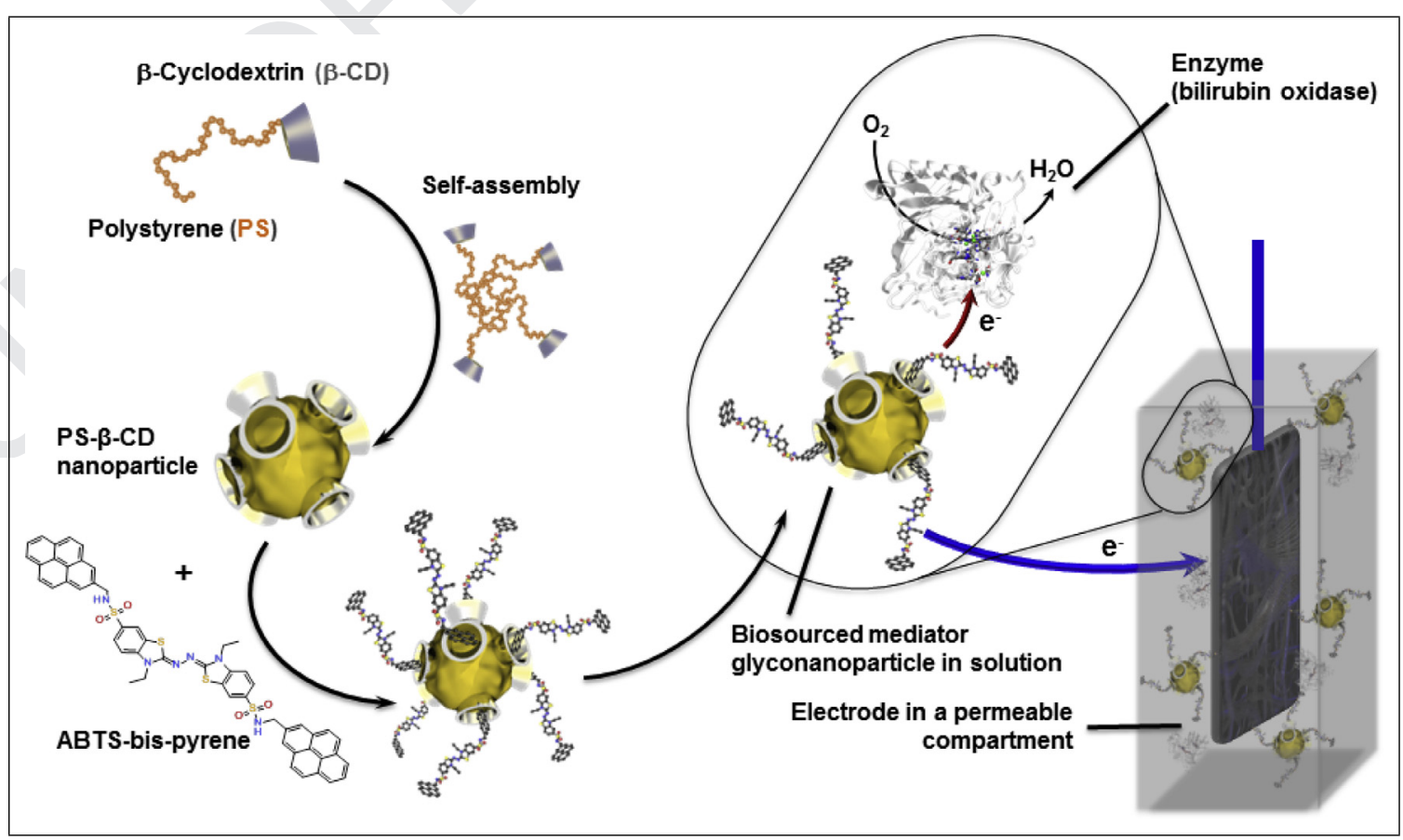

Scheme illustrating the formation and modification of redox-active glyconanoparticles used for construction of an "all in solution" biocathode. 
substrates is envisaged. For enzymes that require or benefit from the use of a redox mediator, bioelectrocatalysis can be ensured using supramolecular assemblies of redox mediator freely diffusing in this chamber. This strategy will overcome the low operational stability of EFCs by allowing the renewal of solubilized enzymes and redox mediators, leading thus to rechargeable EFCs. This concept can also enhance the electrical wiring process, for example, via rotation and redox-hopping effects, and should lead to increased fuel cell performance. Recently, the first step of this unconventional approach was conceived with biosourced nanoparticles functionalized with $\beta$-cyclodextrin groups [62]. For construction of a biocathode, the nanoparticles were modified via host-guest interactions with bis-pyrene-ABTS and used as electron shuttles to facilitate electron transfer between the electrode and bilirubin oxidase in solution (Figure 3). The redox nanoparticles led to enhanced catalytic currents and improved stability for $\mathrm{O}_{2}$ reduction compared to the same electro-enzymatic system with ABTS in solution $\left[63^{\circ}\right]$.

\section{Conclusion}

A significant number of emerging directions for EFCs are now under exploration, such as metabolon systems for cascade reactions of sequential enzymes $\left[64,65^{\circ}\right]$, hybrid fuel cells that seek to combine the advantages of metals and enzymes [66], engineered enzymes with enhanced thermal stability [67], the use of molecular catalysts that mimic enzyme activity with very large turnover frequencies and high stability $\left[68^{\circ}\right]$, and the integration of supercapacitors into fuel cell devices [69]. Another key emerging area concerns biofuel cell power management systems and the incorporation of energy storage systems such as capacitors to prolong biofuel cell lifetime for practical applications $[70,53]$. The promises and challenges of this exciting research field now require truly interdisciplinary research efforts between chemists, surface scientists, bio-scientists, electronic engineers and materials scientists. Despite the presence of technological obstacles to circumvent, there are real potential applications for EFCs ranging from implantable EFCs, for periodic monitoring of diseases during short periods (1-3 months), to totally biodegradable EFCs for disposable medical devices.

\section{Acknowledgement}

The authors are grateful to the Agence Nationale de la Recherche for funding (ANR-15-JTIC-0002-01).

\section{Declarations}

None.

\section{References and recommended reading}

Papers of particular interest, published within the period of review, have been highlighted as:

$$
\begin{aligned}
& \text { - Paper of special interest } \\
& \text { - Paper of outstanding interest. }
\end{aligned}
$$

1. Zhao C, Gai P, Song R, Chen Y, Zhang J, Zhu J-J: Nanostructured material-based biofuel cells: recent advances and future prospects. Chem Soc Rev 2017, 46:1545-1564.

2. Santoro C, Arbizzani C, Erable B, leropoulos I: Microbial fuel cells: from fundamentals to applications. A review. J Power Sources 2017, 356:225-244.

3. Bandodkar AJ: Review-wearable biofuel cells: Past, present and future. J Electrochem Soc 2017, 164:H3007-H3014.

4. Rasmussen M, Abdellaoui S, Minteer SD: Enzymatic biofuel cells: 30 years of critical advancements. Biosens Bioelectron 2016 , 76:91-102.

5. Bandodkar AJ, You J-M, Kim N-H, Gu Y, Kumar R, Mohan AMV,

- Kurniawan J, Imani S, Nakagawa T, Parish B, Parthasarathy M, Mercier PP, Xu S, Wang J: Soft, stretchable, high power density electronic skin-based biofuel cells for scavenging energy from human sweat. Energy Environ Sci 2017, 10:1581-1589.

The highest power density wearable EFC cell to date and the first example for powering a bluetooth low energy radio. The biofuel cell device with integrated DC-DC converter can withstand repeated mechanical strains and was demonstrated for actual in-vivo energy harvesting from the sweat of human subjects

6. Cosnier S, Gross AJ, Goff AL, Holzinger M: Recent advances on - enzymatic glucose/oxygen and hydrogen/oxygen biofuel cells: achievements and limitations. J. Power Sources 2016, 325:252-263.

This paper presents an overview of recent advances in the fields of both glucose and hydrogen biofuel cells, and highlights the impact of new nanostructured electrode materials for enzyme wiring

7. leropoulos IA, Stinchcombe A, Gajda I, Forbes S,

- Merino-Jimenez I, Pasternak G, Sanchez-Herranz D, Greenman J: Pee power urinal - Microbial fuel cell technology field trials in the context of sanitation. Environ. Sci. Water Res. Technol. 2016, 2:336-343.

This paper demonstrates the feasibility of generating several hundreds of mWs from urine using modular MFCs for internal lighting. This is the first time that urinal field trials were used in a practical setting in the context of sanitation and public health

8. Tommasi T, Lombardelli G: Energy sustainability of microbial fue cell (MFC): a case study. J Power Sources 2017, 356:438-447.

9. Pasternak G, Greenman J, leropoulos IA: Self-powered, autonomous biological oxygen demand biosensor for online water quality monitoring. Sens Actuators B Chem 2017, 244:815-822.

10. Mazurenko I, de Poulpiquet A, Lojou E: Recent developments in high surface area bioelectrodes for enzymatic fuel cells. Curr Opin Electrochem 2017, 5:74-84.

11. Saboe PO, Conte E, Farell M, Bazan GC, Kumar M: Biomimetic and bioinspired approaches for wiring enzymes to electrode interfaces. Energy Environ Sci 2017, 10:14-42.

12. Tsujimura S, Murata K, Akatsuka W: Exceptionally high glucose - current on a hierarchically structured porous carbon electrode with "Wired" flavin adenine dinucleotide-dependent glucose dehydrogenase. J Am Chem Soc 2014, 136:14432-14437.

This paper demonstrates exceptionally high catalytic currents at templated mesoporous carbons using the FAD-GDH enzyme, and brings forward the important concept of pore size engineering for bioelectrocatalysis

13. Kwon $\mathrm{CH}$, Lee S-H, Choi Y-B, Lee JA, Kim SH, Kim H-H, Spinks GM, Wallace GG, Lima MD, Kozlov ME, Baughman RH, Kim SJ: Nat Commun 2014, 5:3928.

14. Mano $\mathrm{N}$ : A. de Poulpiquet, ${ }^{02}$ reduction in enzymatic biofue cells. Chem Rev 2017, 5:2392-2468.

15. Cosnier S, Goff AL, Holzinger M: Towards glucose biofuel cells implanted in human body for powering artificial organs: review. Electrochem Commun 2014, 38:19-23.

16. Reuillard B, Abreu C, Lalaoui N, Le Goff A, Holzinger M, Ondel O, Buret F, Cosnier S: One-year stability for a glucose/oxygen biofuel cell combined with $\mathrm{pH}$ reactivation of the laccase/carbon nanotube biocathode. Bioelectrochemistry 2015, 106:73-76. 
17. Mazurenko I, Wang $X$, de Poulpiquet $A$, Lojou E: $\mathbf{H}_{2} / \mathrm{O}_{2}$ enzymatic

- fuel cells: from proof-of-concept to powerful devices. Sustain Energy Fuels 2017, 1:1475-1501.

This review summarizes the latest advances in the field of $\mathrm{H}_{2} / \mathrm{O}_{2}$ EFCs in terms of hydrogenase immobilization, hydrogenase structure, electrode nanostructuration, enzyme engineering, and the use of thermostable enzymes

18. Xu L, Armstrong FA: Pushing the limits for enzyme-based - membrane-less hydrogen fuel cells - achieving useful power and stability. RSC Adv 2014, 5:3649-3656.

This paper describes " $3 \mathrm{D}$ " porous hydrogenase electrodes combined in an EFC stack design that operates in parallel or in series

19. Jones AK, Sillery E, Albracht SPJ, Armstrong FA: Direct comparison of the electrocatalytic oxidation of hydrogen by an enzyme and a platinum catalyst. Chem Commun 2002, 0:866-867.

20. Alonso-Lomillo MA, Rüdiger O, Maroto-Valiente A, Velez M, Rodríguez-Ramos I, Muñoz FJ, Fernández VM, De Lacey AL: Hydrogenase-coated carbon nanotubes for efficient $\mathrm{H}_{2}$ oxidation. Nano Lett 2007, 7:1603-1608.

21. Ciaccafava A, Infossi P, Ilbert M, Guiral M, Lecomte S Giudici-Orticoni MT, Lojou E: Electrochemistry, AFM, and PM-IRRA spectroscopy of immobilized hydrogenase: Role of a hydrophobic helix in enzyme orientation for efficient $\mathbf{H}_{2}$ oxidation. Angew Chem Int Ed 2012, 51:953-956.

22. Liu J, Wu W-J, Fang F, Zorin NA, Chen M, Qian D-J: Immobilization of hydrogenase on carbon nanotube polyelectrolytes as heterogeneous catalysts for electrocatalytic interconversion of protons and hydrogen. $J$ Nanoparticle Res 2016, 18:220.

23. Karyakin AA, Morozov SV, Karyakina EE, Varfolomeyev SD, Zorin NA, Cosnier S: Hydrogen fuel electrode based on bioelectrocatalysis by the enzyme hydrogenase. Electrochem Commun 2002, 4:417-420.

24. Morozov SV, Vignais PM, Cournac L, Zorin NA, Karyakina EE, - Karyakin AA, Cosnier S: Bioelectrocatalytic hydrogen production by hydrogenase electrodes. Int $J$ Hydrog Energy 2002, 27:1501-1505.

This is the first report of a redox polypyrrole-hydrogenase electrode. This paper also demonstrates the production of hydrogen by mass spectrometry and electrochemistry

25. Morozov SV, Voronin OG, Karyakina EE, Zorin NA, Cosnier S, Karyakin AA: Tolerance to oxygen of hydrogen enzyme electrodes. Electrochem Commun 2006, 8:851-854.

26. Karyakin AA, Morozov SV, Voronin OG, Zorin NA, Karyakina EE Fateyev VN, Cosnier S: The limiting performance characteristics in bioelectrocatalysis of hydrogenase enzymes. Angew Chem Int Ed 2007, 46:7244-7246.

27. Pandelia M-E, Fourmond V, Tron-Infossi P, Lojou E, Bertrand P Léger C, Giudici-Orticoni M-T, Lubitz W: Membrane-bound hydrogenase I from the hyperthermophilic bacterium aquifex aeolicus: enzyme activation, redox intermediates and oxygen tolerance. J Am Chem Soc 2010, 132:6991-7004.

28. Vincent KA, Cracknell JA, Lenz O, Zebger I, Friedrich B, Armstrong FA: Electrocatalytic hydrogen oxidation by an enzyme at high carbon monoxide or oxygen levels. Proc Natl Acad Sci 2005, 102:16951-16954.

29. Xu L, Armstrong FA: Optimizing the power of enzyme-based membrane-less hydrogen fuel cells for hydrogen-rich $\mathrm{H}_{2}$-air mixtures. Energy Environ Sci 2013, 6:2166-2171.

30. Plumeré N, Rüdiger O, Oughli AA, Williams R, Vivekananthan J Pöller S, Schuhmann W, Lubitz W: A redox hydrogel protects hydrogenase from high-potential deactivation and oxygen damage. Nat Chem, vol 62014.

31. Fourmond V, Stapf S, Li H, Buesen D, Birrell J, Rüdiger O, Lubitz W, Schuhmann W, Plumeré N, Léger C: Mechanism of protection of catalysts supported in redox hydrogel films. J Am Chem Soc 2015, 137:5494-5505.
32. Gamella M, Koushanpour A, Katz E: Biofuel cells - activation of micro- and macro-electronic devices. Bioelectrochemistry 2018 119:33-42.

33. Talla V, Kellogg B, Gollakota S, Smith JR: Battery-Free Cellphone. Proc ACM Interact Mob Wearable Ubiquitous Technol, vol 12017 25:1-25:20.

34. Rajendran L, Kirthiga M, Laborda E: Mathematical modeling of nonlinear reaction-diffusion processes in enzymatic biofuel cells. Curr Opin Electrochem 2017, 1:121-132.

35. Gross AJ, Chen X, Giroud F, Abreu C, Le Goff A, Holzinger M,

- Cosnier S: A high power buckypaper biofuel cell: exploiting 1,10-phenanthroline-5,6-dione with FAD-dependent dehydrogenase for catalytically-powerful glucose oxidation. ACS Catal 2017, 7:4408-4416.

This report demonstrates the preparation of lab-made buckypaper electrodes which exhibit excellent voltammetry and their use for the construction of a high power glucose $/ \mathrm{O}_{2}$ biofuel cell with the emerging FAD-GDH enzyme at the anode

36. Stoilova I, Krastanov A, Stanchev V: Properties of crude laccase from Trametes versicolor produced by solid-substrate fermentation. Adv Biosci Biotechnol 2010, 01:208.

37. Tasca F, Farias D, Castro C, Acuna-Rougier C, Antiochia R Bilirubin oxidase from Myrothecium verrucaria physically absorbed on graphite electrodes. Insights into the alternative resting form and the sources of activity loss. PLOS One, vol 10 2015 e0132181.

38. Gouda MD, Singh SA, Rao AGA, Thakur MS, Karanth NG: Therma inactivation of glucose oxidase: mechanism and stabilization using additives. J Biol Chem 2003, 278:24324-24333.

39. El-Sherbeny GA, Shindia AA, Sheriff YMMM: Optimization of various factors affecting glucose oxidase activity produced by Aspergillus niger. Int J Agric Biol 2005, 7:953-958.

40. Singh J, Verma N: Glucose oxidase from Aspergillus niger: Production, characterization and immobilization for glucose oxidation. Adv App/ Sci Res 2013, 4:250-257.

41. de Poulpiquet A, Ciaccafava A, Gadiou R, Gounel S, Giudici-Orticoni MT, Mano N, Lojou E: Design of a $\mathrm{H}_{2} / \mathrm{O}_{2}$ biofuel cell based on thermostable enzymes. Electrochem Commun 2014, 42:72-74.

42. Monsalve K, Mazurenko I, Lalaoui N, Le Goff A, Holzinger M, Infossi P, Nitsche S, Lojou JY, Giudici-Orticoni MT, Cosnier S, Lojou E: $\mathrm{A} \mathrm{H}_{2} / \mathrm{O}_{2}$ enzymatic fuel cell as a sustainable power for a wireless device. Electrochem Commun 2015, 60:216-220.

43. Cadet M, Gounel S, S-Chaumeil C, Brilland X, Rouhana J, Louerat $F$, Mano N: An enzymatic glucose/O2 biofuel cell operating in human blood. Biosens Bioelectron 2016 83:60-67.

44. Kwon CH, Lee JA, Choi Y-B, Kim H-H, Spinks GM, Lima MD, Baughman $\mathrm{RH}$, Kim SJ: Stability of carbon nanotube yarn biofuel cell in human body fluid. J Power Sources 2015, 286:103-108.

45. Milton RD, Lim K, Hickey DP, Minteer SD: Employing FAD-dependent glucose dehydrogenase within a glucose/oxygen enzymatic fuel cell operating in human serum Bioelectrochemistry 2015, 106:56-63.

46. Ó Conghaile $\mathrm{P}$, Falk M, MacAodha D, Yakovleva ME, Gonaus C, Peterbauer CK, Gorton L, Shleev S, Leech D: A fully enzymatic membrane-less glucose|oxygen fuel cell provides $0.275 \mathrm{~mA}$ $\mathrm{cm}-2$ in $5 \mathrm{mM}$ glucose operates in human physiological solutions and powers transmission of sensing data. Anal Chem 2016, 88:2156-2163.

47. Gobel G, Beltran ML, Mundhenk J, Heinlein T, Schneider J Lisdat F: Operation of a carbon nanotube-based glucose/oxygen biofuel cell in human body liquids-performance factors and characteristics. Electrochim Acta 2016, 218:278-284

48. Cinquin $\mathrm{P}$, Gondran $\mathrm{C}$, Giroud F, Mazabrard S, Pellissier A, Boucher F, Alcaraz J-P, Gorgy K, Lenouvel F, Mathé S, Porcu P, 
8 Bioelectrochem

Cosnier S: A glucose bioFuel cell implanted in rats. PLOS ONE 2010, 5:e10476.

49. Gross A, Holzinger M, Cosnier S: Buckypaper bioelectrodes: - Emerging materials for implantable and wearable biofuel cells. Energy Environ Sci 2018. https://doi.org/10.1039/C8EE00330K.

This paper is the first review on buckypapers in the field of (bio)electrochemistry and biofuel cell research for body-integrated applications

50. Villarrubia CWN, Soavi F, Santoro C, Arbizzani C, Serov A Rojas-Carbonell S, Gupta G, Atanassov P: Self-feeding paper based biofuel cell/self-powered hybrid $\boldsymbol{\mu}$-supercapacitor integrated system. Biosens Bioelectron 2016, 86:459-465.

51. Halámková L, Halámek J, Bocharova V, Szczupak A, Alfonta L, -. Katz E: Implanted biofuel cell operating in a living snail. J Am Chem Soc 2012, 134:5040-5043.

This was the first example of an EFC based on commercial buckypaper implanted in a live animal in a natural environment. The power was demonstrated continuously over 2 weeks and could be metabolically recharged upon feeding or resting of the snail

52. Fokina O, Eipper J, Winandy L, Kerzenmacher S, Fischer R: Improving the performance of a biofuel cell cathode with laccase-containing culture supernatant from pycnoporus sanguineus. Bioresour Technol 2015, 175:445-453.

53. Hou C, Liu A: An integrated device of enzymatic biofuel cells and supercapacitor for both efficient electric energy conversion and storage. Electrochim Acta 2017, 245:303-308.

54. MacVittie K, Halámek J, Halámková L, Southcott M, Jemison WD,

-• Lobel R, Katz E: From "cyborg" lobsters to a pacemaker powered by implantable biofuel cells. Energy Environ Sci 2013 6:81-86.

The first paper to address the problem of interfacing electronics with implantable glucose $/ \mathrm{O}_{2}$ EFCs. This paper highlighted the unfortunate issue of tissue conductivity which prevented biofuel cell operation in series in the same organism. Successful activation of a watch was nevertheless demonstrated from in-vivo fuel cells in multiple organisms

55. MacVittie K, Conlon T, Katz E: A wireless transmission system powered by an enzyme biofuel cell implanted in an orange. Bioelectrochemistry 2015, 106:28-33.

56. Reid RC, Minteer SD, Gale BK: Contact lens biofuel cell tested in a synthetic tear solution. Biosens Bioelectron 2015, 68:142-148.

57. Bourourou M, Elouarzaki K, Holzinger $M$, Agnès $C$, Le Goff $A$, Reverdy-Bruas N, Chaussy D, Party M, Maaref A, Cosnier S: Freestanding redox buckypaper electrodes from multi-wall carbon nanotubes for bioelectrocatalytic oxygen reduction via mediated electron transfer. Chem Sci 2014, 5:2885-2888.

58. Elouarzaki K, Bourourou M, Holzinger M, Goff AL, Marks RS, Cosnier S: Freestanding HRP-GOx redox buckypaper as an oxygen-reducing biocathode for biofuel cell applications. Energy Environ Sci 2015, 8:2069-2074.

59. Cosnier S, Haddad R, Moatsou D, O'Reilly RK: Biofunctionalizable flexible bucky paper by combination of multi-walled carbon nanotubes and polynorbornene-pyrene Application to the bioelectrocatalytic reduction of oxygen. Carbon 2015, 93:713-718.
60. Gross AJ, Robin MP, Nedellec Y, O'Reilly RK, Shan D, Cosnier S: Robust bifunctional buckypapers from carbon nanotubes and polynorbornene copolymers for flexible engineering of enzymatic bioelectrodes. Carbon 2016, 107:542-547.

61. Ciniciato GPMK, Lau C, Cochrane A, Sibbett SS, Gonzalez ER, Atanassov P: Electrochim Acta 2012, 82:208-213.

62. Gross AJ, Haddad R, Travelet C, Reynaud E, Audebert P, Borsali R Cosnier S: Redox-active carbohydrate-coated nanoparticles: self-assembly of a cyclodextrin-polystyrene glycopolymer with tetrazine-naphthalimide. Langmuir 2016, 32:11939-11945.

63. Gross AJ, Chen X, Giroud F, Travelet C, Borsali R, Cosnier S

- Redox-active glyconanoparticles as electron shuttles for mediated electron transfer with bilirubin oxidase in solution. $J$ Am Chem Soc 2017, 139:16076-16079.

The first enzyme wiring by organic redox nanoparticles is described and demonstrated for $\mathrm{O}_{2}$ reduction via mediated electron transfer. This paper reports the self-assembly, characterization and bioelectrocatalysis of $\beta$-cyclodextrin-based nanoparticles with enzyme in solution

64. Liu Y, Hickey DP, Guo J-Y, Earl E, Abdellaoui S, Milton RD, Sigman MS, Minteer SD, Calabrese Barton S: Substrate channeling in an artificial metabolon: a molecular dynamics blueprint for an experimental peptide bridge. ACS Catal 2017. 7:2486-2493.

65. Wheeldon I, Minteer SD, Banta S, Barton SC, Atanassov P,

-. Sigman M: Substrate channelling as an approach to cascade reactions. Nat Chem 2016, 8:299-309.

This work describes different natural and non-natural approaches for channeling substrates between enzyme active sites for cascade reactions for catalyzing sequential reactions

66. Majdecka D, Draminska S, Janusek D, Krysinski P, Bilewicz R: A self-powered biosensing device with an integrated hybrid biofuel cell for intermittent monitoring of analytes. Biosens Bioelectron 2018, 102:383-388.

67. K. Sode, K. Mori, Glucose dehydrogenase, US Pat., 8999691B2, 2015.

68. Gentil S, Lalaoui N, Dutta A, Nedellec Y, Cosnier S, Shaw WJ,

- $\quad$ Artero V, Le Goff A: Carbon-nanotube-supported bio-inspired nickel catalyst and its integration in hybrid hydrogen/air fuel cells. Angew Chem Int Ed 2017, 56:1845-1849.

The most efficient example of a hybrid $\mathrm{H}_{2} / \mathrm{O}_{2}$ EFC to date which exploits a bioinspired complex at the anode with an enzymatic biocathode

69. Xiao X, Conghaile PÓ, Leech D, Ludwig R, Magner E: A symmetric supercapacitor/biofuel cell hybrid device based on enzyme-modified nanoporous gold: an autonomous pulse generator. Biosens. Bioelectron 2017, 90:96-102.

70. Abreu C, Nedellec Y, Gross AJ, Ondel O, Buret F, Le Goff A, Holzinger M, Cosnier S: Assembly and stacking of flow-through enzymatic bioelectrodes for high power glucose fuel cells. ACS Appl Mater Interfaces 2017, 9:23836-23842. 